\title{
Examining the Effects of the Industrial Revolution on Furniture
}

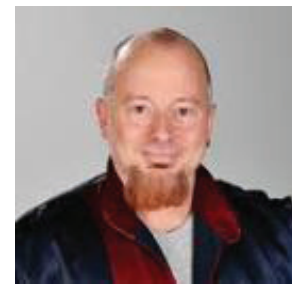

\author{
Lecturer Şerif Tolga ERDEM \\ İstanbul Kultur University \\ Department of Interior Architecture \&Environmental Design \\ t.erdem@iku.edu.tr
}

Abstract: Furniture is a phenomenon that takes place in human life as a design product. This phenomenon is located at the intersection of many fields of study that seem distant from each other, such as engineering, natural sciences, and art approaches in their historical process. When looking at the historical process of furniture, if the term furniture designer is used, it can be seen that these designers are sometimes an artist, architect, artisan, engineer, industrial product designer and interior designer. These disciplines and professional groups, which have differences in common as well as common aspects, can be considered as an indication of the extent of furniture occupying human life. This study was carried out to investigate the effects of the industrial revolution on furniture design.

Keywords: Furniture, The Industrial Revolution, Design

\section{Endüstri Devriminin Mobilya Üzerindeki Etkilerinin İncelenmesi}

Öz: Mobilya, bir tasarım ürünü olarak insanın yaşamında yer alan bir olgudur. Bu olgu, tarihsel sürecinde mühendislik, doğa bilimleri, sanat yaklaşımları gibi birbirinden uzak görünen birçok çalışma alanının kesiştiği bir noktada bulunmaktadır. Mobilyanın tarihi sürecine bakıldı̆̆ında, genel olarak mobilya tasarımcısı ifadesi kullanılırsa, bu tasarımcıların bazen bir sanatçı, mimar, zanaatkâr, mühendis, endüstri ürünleri tasarımcısı ve iç mimar oldukları görülebilir. Ortak yönleri olduğu kadar birbirinden farklılıkları da olan bu disiplin ve meslek grupları, mobilyanın insan yaşantısında ne derecede yer kapladiğının bir göstergesi olarak da düşünülebilir. Bu çalışma, endüstri devriminin mobilya tasarımı üzerindeki etkilerini araştırarak ortaya koymak amacıyla yapılmıştır.

Anahtar Kelimeler: Mobilya, Endüsrti Devrimi, Tasartm

\section{INTRODUCTION}

Furniture is a concept that takes place in human life as a design product. This concept is located at the intersection of many fields of study that seem distant from each other, such as engineering, natural sciences, and artistic approaches in their historical process. When we look at the historical process of furniture, if the term furniture designer is used, we can be seen that these designers are sometimes an artist, architect, craftsman, engineer, industrial product designer, and interior designer. These disciplines and occupational groups, which have common aspects as well as differences, can be considered as an indicator of how important the furniture is in human life.

Furniture has been one of the main indicators of the cultural structures of societies that adopted settled life. With the establishment of the hierarchical order in societies over time, not only functionality but also prestige has become a necessity and attached to furniture. Furniture, which is limited to meeting needs such as sitting, eating, sleeping, has turned into tools that symbolize a privilege. The changes in the socio-cultural structures of societies based on the time have accelerated and diversified by being compatible with the

Doi Num : 10.17932/IAU.ARCH.2015.017/arch_v05i2005 
innovations in the fields of the industrial revolution, materials, and production techniques. This study was carried out to investigate the effects of the industrial revolution on furniture design.

\section{DEFINITION OF FURNITURE}

Furniture is a product of societies that have adopted a settled life and that are developed. One of the basic elements of people's living spaces is furniture. Furniture is defined by common expressions not far from each other; Basic physical needs such as sitting, sleeping, working and storage [1]. Furniture is an item used to make human life easier and make the living space more comfortable [2]. There are many types of furniture, from the most well-known, such as chairs, tables, beds, cabinets, armchairs, to the least known, such as radiators, kitchen units, fireplaces and even door accessories. Furniture can also be fittings in a space. Fixed furniture can also be used as a dividing element in the space instead of walls [3].

Furniture is generally household goods made of materials such as wood, metal, plastic, glass, fabric. The word "furniture" in English is originally based on the word "fourniture" in French. Fourniture; means equipment. In European languages other than English, instead of the word "fourniture", the adjective "mobile" (German: möble, French: meuble, Spanish: meuble and Italian: mobile), the Latin origin "mobilis", is used. The furniture experience of Continental Europe is considered more descriptive. Equipment must be mobile to be furniture [4]. Furniture is an item used to decorate the living places and to equip them for various purposes [5]. Ching does not make a different definition for furniture but expresses it as a covering element [6]. Depending on the function, Luice - Smith describe furniture as an item that develops and changes based on four basic elements; function, social status, technical developments and the needs of daily life [7]. Similarly, Boyla also describes these as items that provide practicality, assist in determining personal private areas, helps its owner to earn and provide information about social status and attitude as well as actions and needs [8]. According to Hoffman, space and furniture are parts of the same unit and they live in the same unit [9].

Looking at the definitions given above, some of the definitions; while it is seen that some of the definitions concentrates on objects such as tables, coffee tables and chairs, some people describe them through the functions of furniture. While Ching sees furniture as an element of the space, Hoffman shows a more plenary approach that indicates furniture is not a space-independent item but it is complementary to the space. Each definition addresses a different focus on furniture. If a general definition is tried to be made by concentrating on the focal points of the different definitions that have been transferred, it can be defined as with the fact that furniture is not a vital necessity, it can be defined as an interior item that provides practicality that is functional, symbolic, social as well as personal.

\section{FURNITURE BEFORE THE INDUSTRIAL REVOLUTION}

In the period until the Industrial Revolution, societies continued their lives with an agriculture-based production style in a feudal structure. In terms of technological and social changes made, the Industrial Revolution was a breaking point in furniture production and consumption. Küçükerman refers to the form of production in the period up to the Industrial Revolution as the production period with manpower [10]. During the period until the 19th century, the production of furniture was based on manpower. In this part of the study, the development of furniture until industrialization has been briefly examined at certain time intervals. 


\subsection{Primeval Era}

The oldest known settlement of the Neolithic period when human beings adopted a settled lifestyle is considered Çatalhöyük. During this period when furniture had not been used yet; some needs were tried to be solved in terms of function as a part of the building with pits and elevations on the ground, coves and shelves on the walls, and the like [11]. The furniture samples of the primeval are seen in Ancient Egypt, Ancient Greece and Rome. Although it is mentioned that the furniture is a personal item, it can be observed that those people were not ordinary people, rather they were the palace seniors, noble or wealthy people. In this case, they are one of the first indications that furniture is a symbol of status and privilege (Figure 1).

No concrete example can be found in Ancient Egypt until the Pharaohs Period. However, through the hand tools, tablet and wall paintings, it is understood and accepted that there were furniture in Ancient Egypt [12].

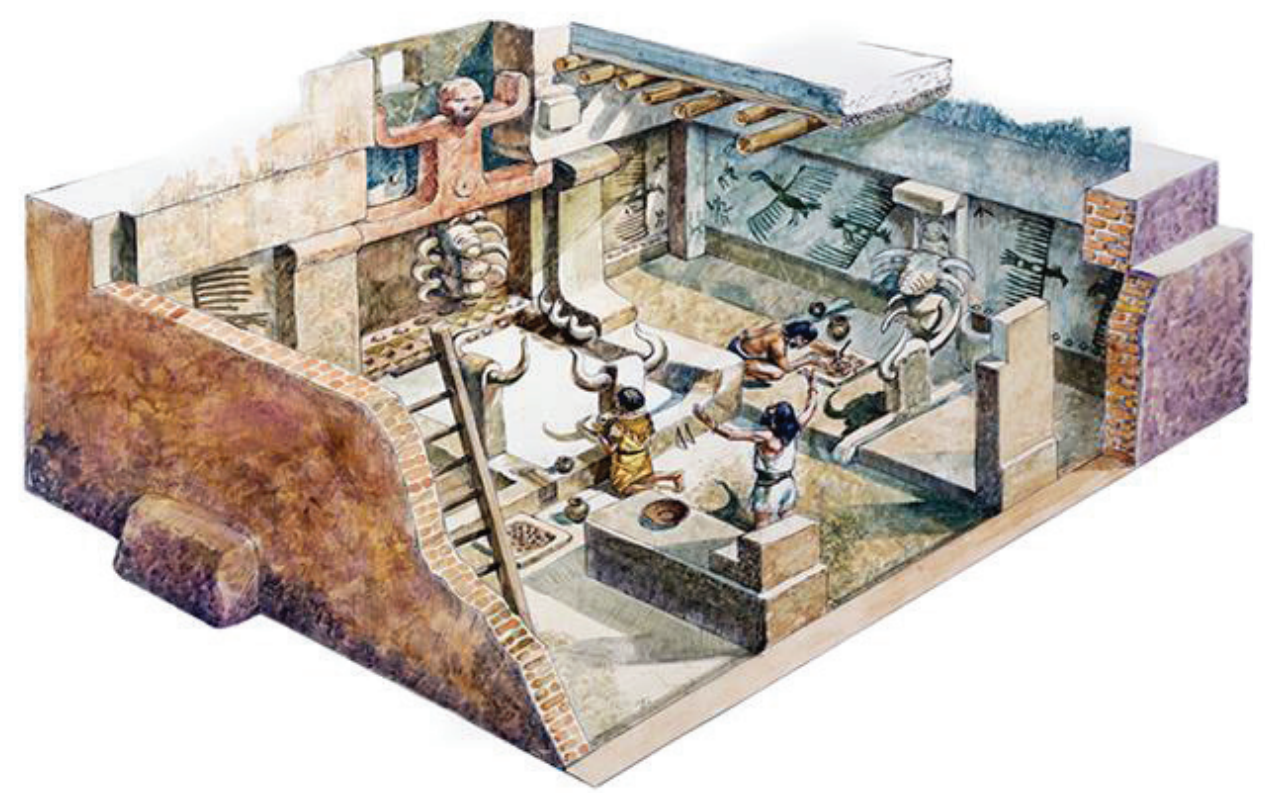

Figure 1. Çatalhöyük [13]

The majority of thrones in the found furniture can be considered as another indication that the people who had furniture were of a privileged segment of the society. It was detected that furniture in the Old and Middle Kingdom Periods was generally a chest and sitting element. In the New Kingdom Period, it is seen that especially the production of chairs was progressed considerably [14]. In addition to being a symbol of social status, it can be said that the furniture in Ancient Egypt was an element for the purpose of sitting and it caused some other functional developments in the sitting action. The improvement in the dimensions of the chair can be considered as the beginning of attributing a functional meaning to the furniture (Figure 2). 


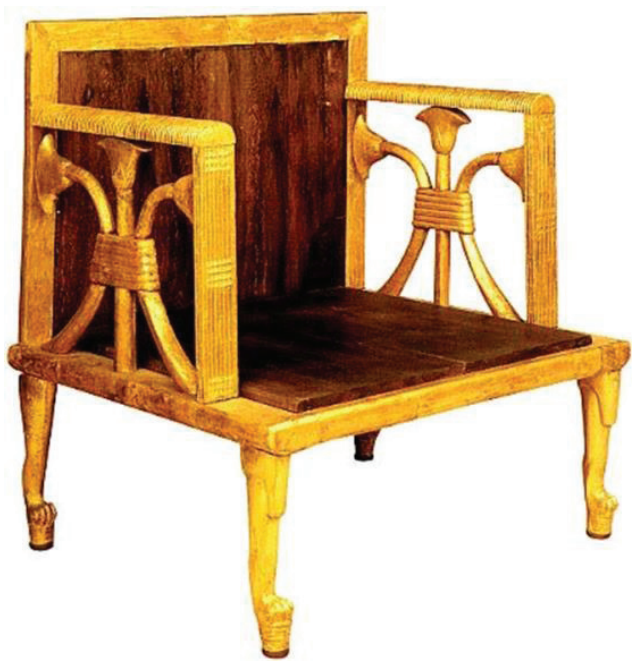

Figure 2. Throne of Queen I. Hetepheres [15]

An example of furniture from ancient Greece could not have been reached. However, stone reliefs, vase pictures and mural paintings give an idea about furniture of that time. The most mentioned of this furniture is the Klismos Chair. Klismos Chair, made in Ancient Greece, is seen as a masterpiece in terms of its simplicity, form and comfort. In the Iliad Epic, Homeros praised Klismos Chair as "Worthy of Goddesses" [15]. Dampierre says that the Klismos Chair has very modern lines and is highly compatible with human ergonomics. As it is stated in various sources, the class-related meaning that furniture carries is supported by the furniture from the ancient period (Figure 3).

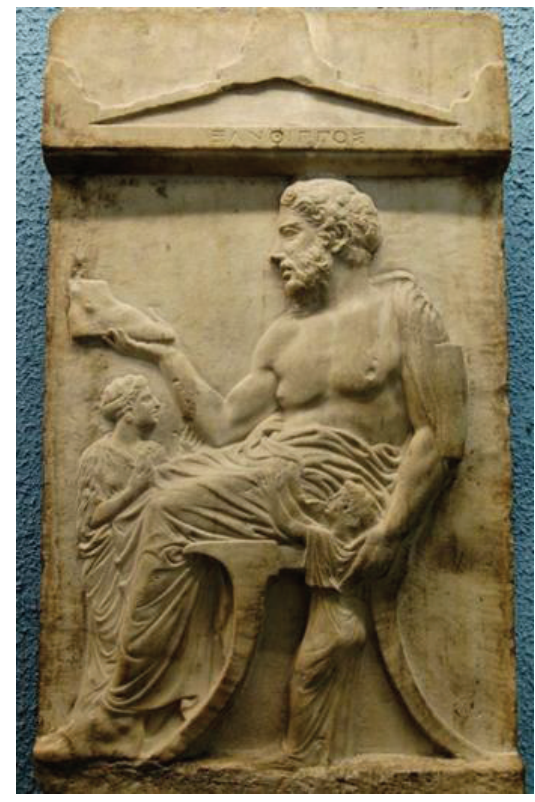

Figure 3. Klismos chair, stone relief [16] 


\subsection{Medieval Ages}

After the fall of the Roman Empire in the 4th century, Europe was buried in darkness for a thousand years. Until about 1100, no development was observed in any field of art. Re-activation in the field of art in Europe caused by the crusaders returning from the Middle East bringing Islamic ideas and influenced by Byzantine Architecture. This influence manifested itself most in France and led to the start of the Gothic Style, which lasted about 400 years. The Gothic Style was effective in almost everything, especially in architecture and furniture, but all these designs were limited to the cathedrals that were considered as the center of the social life of that time [17]. In Medieval Europe, it is observed that the transition to settled life turned into an urbanization process. The social changes that emerged with urbanization created a middle class that was not included in the clergy, but could own land thanks to the development of the property rights. That middle class would form the mass demanding furniture after the church and palace seniors.

\subsection{Renaissance}

Renaissance is considered as the period when the Western World underwent major cultural changes. As the main negative effects on the formation of this cultural change environment: the feudal order of the Middle Ages, its economic structure, and the social, strict, scholastic attitude of the churches can be counted. As opposed to these negative factors, invention of the printing press, the development of commerce, and the fact that wealthy groups formed in cities invested in non-religious areas can be counted as positive factors in the development of the Renaissance.

Renaissance Furniture is generally seen as rough, bulky furniture that is not very different from that of the previous periods. As a reflection of the progress in mathematics science and tool making, it is seen that fine workmanship such as carving and inlay increased in the furniture of the period. The increase of guilds in the 16th century was one of the factors that increased branching out and specializing in furniture. Some of the guilds among furnishers were: framer, upholsterer, platformer, veneerer, inlayer, painter, metal accessory maker [17].

\subsection{Baroque}

Baroque style was born in Rome. It reached its brightest period in the middle of the 17th century. Towards the end of the 17th century, France became the unquestionable leader of Europe in the Baroque Style [18]. The structure and decorations used were taken from Ancient Roman Architecture in general, but the shapes became more curved and the surfaces more complex than the Ancient Roman Architecture (Figure 4). With the development of trade, it was observed that bourgeois class also competed each other to have furniture along with the wealthy nobles [18]. 


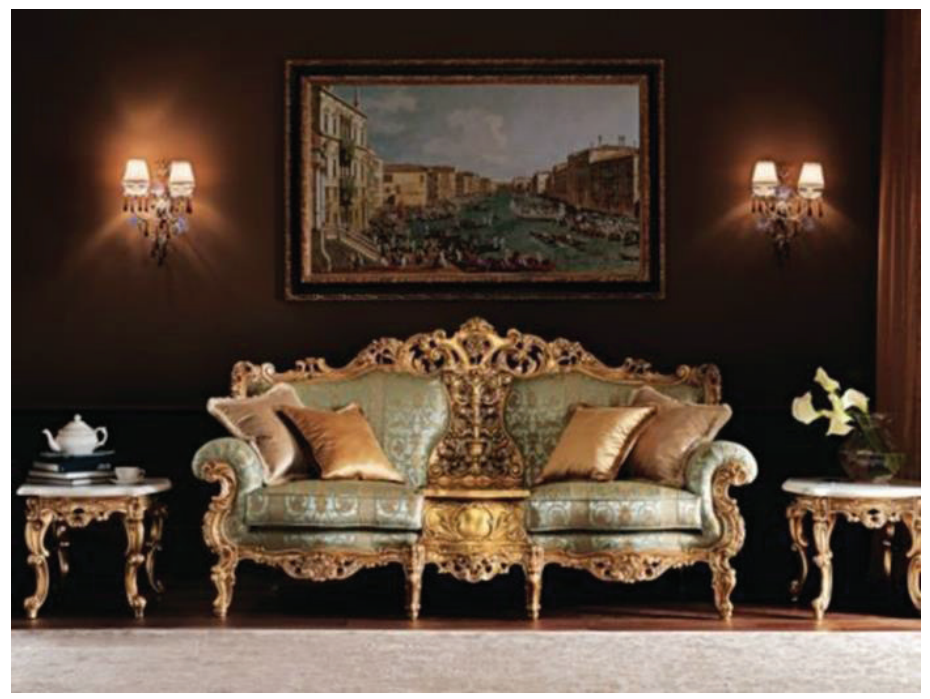

Figure 4. Baroque Style [19]

\subsection{Rococo}

Following the Baroque Style, in which form and decoration are important, Rococo was observed in France as of the beginning of the 18th century. In the emergence of Rococo, the aristocrats and the bourgeois class gradually approached each other in terms of wealth, and it can be said that the masters trained in the guilds, which started to become widespread with the Renaissance, were protected by the bourgeois class and there was a tendency for orders in accordance with the personal tastes. When we look at the first examples of the Rococo style, we see that there were abundant adornments and flourish, as in Baroque style. As the style progressed, we see that simpler products appeared. In the French Palace of the time, the emergence of private life, new forms of social behavior, such as coffee, tea, and morning coffee, five o'clock tea routines, which were learned as a result of overseas trade, also caused new and different searches [14]. The need for privacy and the disturbance caused by the fact that the servants were always around their masters led to a need for designing the spaces and tools in a way that they can be used without help. The fact that the room types became more distinctive brought an idea along with that rather than moving the furniture, furniture and architecture started to be considered together [8]. In line with these changes, it can be said that the furniture was more plain, light and useful in the period when furniture design was directed towards the search for function and elegance. Although ergonomics were not in question yet, the fact that the backs were made with a certain slope, not upright, can be interpreted as comfort and ergonomic concerns began at that time.

If we look at the change that the furniture went through since the early days and till the end of the primeval era, we can summarize it briefly as follows; In the prehistoric times, in the first ruins, it is seen that the furniture was used to meet the needs functionally and be a solution for the living space structurally. In ancient times, the furniture was built and used to symbolize the privilege, exclusivity and authority of a certain class. With the Middle Ages, a tendency towards more individual forms and purposes was observed. As a result of its reflection with the Renaissance, it is in question that there were more ergonomic designs compatible with the human in furniture compared to the previous periods. 


\section{THE INDUSTRIAL REVOLUTION}

The Industrial Revolution or Technological Revolution began in 1765 with the invention of Scotsman James Watts' steam engine. The Industrial Revolution affected England firstly and then the rest of the world. As a result of this invention of Watts, great developments were made with mechanization in iron, steel processing, and coal mining. In addition, huge steps were taken in modern transportation tools and lines. The developments enabled many new designs works to emerge and provided opportunities to build railways, hotels, canals, led to growing cities and new architectural designs (Figure 5).

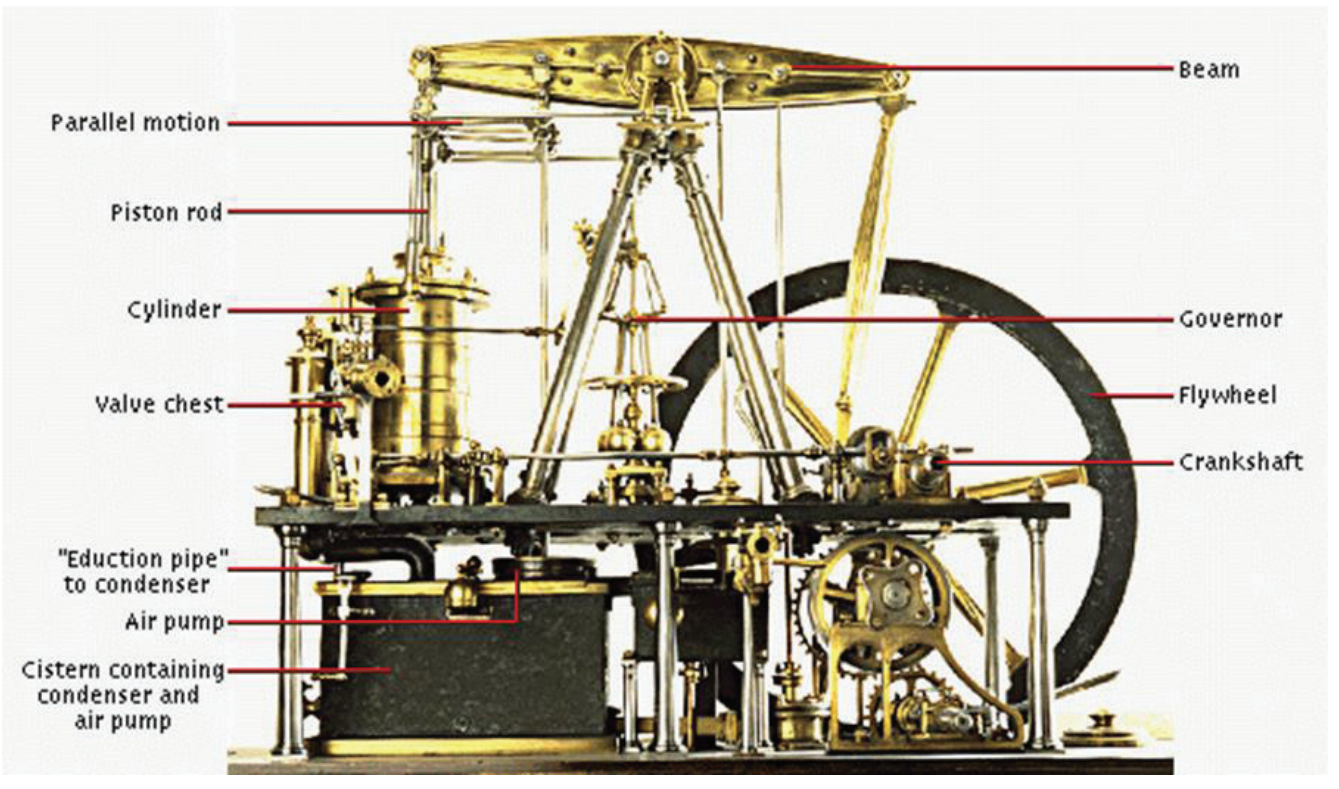

Figure 5. James Watt, Steam Engine 1765 [20]

The Industrial Revolution enabled the transition from expensive and time-consuming manual workmanship to a much faster and cheaper machine business, and thus many products began to reach larger masses of people. It can be said that the Industrial Revolution not only caused radical changes in production, but also important social changes. Although the Industrial Revolution was a European originated change, it caused large-scale changes both in the social structure and in the production forms all over the world. As a result of the changes in the means of production tools, the shift of the population to the cities, the emergence of new professions and the formation of classes in the society are the phenomenon associated with the Industrial Revolution in general. With the mechanization developed in parallel with industrialization, not only the production methods but also the products themselves changed. Although we say that Industrial Revolution started with James Watt's invention of the steam engine, the Industrial Revolution is a phenomenon that did not occur with a single invention or a social movement but occurred in the process gradually.

\subsection{Industrialization}

In human history, we can talk about two milestones. The first of these is the Agricultural Revolution, which started with the adoption of settled lifestyle and cultivation of the soil, and the second is the Industrial Revolution. The Industrial Revolution is also defined as the transformation of the agricultural population into a producer of goods and services [15]. Industrialization, in the narrow sense, can be defined as the use of machinery in production or the increase in the share of the industry segment in the national income, in a broad sense, it can be described as the changes that the countries underwent in economic, political and 
social, etc. fields [17]. Arnold Toynbee used the term Industrial Revolution for the first time. He described it as a very rapid change that took place in England between 1750 and 1850 and spread to other western countries over time [18]. Küçükerman named the form of production in the period until the Industrial Revolution in the 19th century as manpower production period [10].

As can be seen in various sources, industrialization caused great variations in the structure of the society with changes in production forms. It can be said that society was reformed with new values such as new business lines and private property. These new values and new lines of business brought along concepts and ideologies that had not existed in the society or had not been so effective before. The technology was the basis of those social changes created by industrialization. The reflections of the changes in technology on the means of production inevitably changed the societies.

\section{THE REFLECTIONS OF THE INDUSTRIAL REVOLUTION ON FURNITURE}

In this part of the study, changes in furniture design and production methods came along with the Industrial Revolution will be discussed. A general chronology will be followed for this time period, which will be examined by the end of the 18th century. These chronological time intervals will be named in accordance with the changes and approaches in furniture design, with the names of the designers or art movements in which the time interval in question is generally mentioned with. The reason for choosing this method is the fact that the changes in the design conceptions did not occur with exact dates point by point and their effects on each other do not have precise distinctions.

\subsection{Michael Thonet}

Born in 1796, Austrian carpenter master Michael Thonet, developed a new technique at the end of the XIX century, and he started to make taborets out of beech tree and sell them. The taborets made by Michael Thonet by softening the beech tree in water vapor and bending it became famous first in Austria and then worldwide. The name "Thonet" became a brand. At the end of the XIX century, he made his first patented mass production in the field of chairs with the works as bending with mold by gluing laminated wooden strip first; and afterwards, bending solid woods (bended by vapor). In fact, the model named No: 14 sold about 50 million units from 1859 to 1930 . In the same type of works, this was a record. This is the first work to use the production line system, so it formed the first steps in the evolution of modernity (Figure 6 and Figure 7). They were elegant and simple forms on which correct proportions were used [21]. 


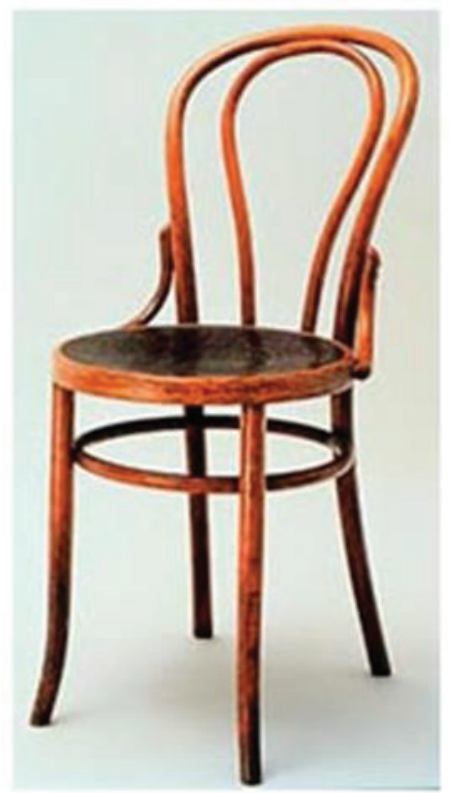

Figure 6. Thonet Chair 1859 [22]

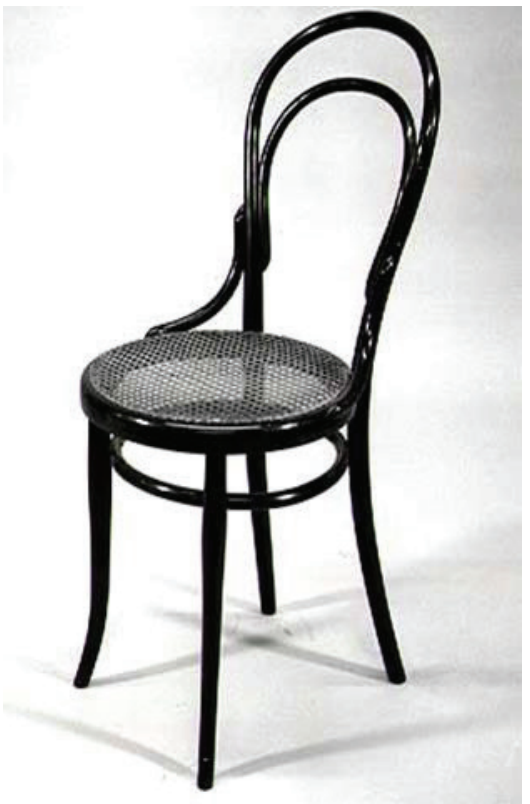

Figure 7. Thonet Chair No: 14 [23]

\subsection{Arts and Crafts Movement}

A group of named Pre-Raffaello people in England advocated the idea of that the nature should be delivered in a plain and honest way. English poetry and legends were taken as the subject. They paid attention to brightness and simplicity in details in pictures. The art of this group also affected the Arts and Crafts movement closely. The British government supported the collaboration of artists and craftsmen since the XVIII century. A public school was established in 1835 to raise the quality and standard in production. At school, John Ruskin and Pre-Raffaello artists worked as teachers. The artisans at the school learned their opinions and ideas. As a result of the industrial revolution, wider ateliers replaced the artisanal works in the workshops with traditional methods thanks to improvements in textile and machinery use. Efforts to combine art and crafts provided job opportunities for craftsmen. British craftsmen did not break from onepiece production, they brought artists from outside to increase production.

Arts and Crafts exhibition group was formed in 1888. In 1860, Morris moved to the Red House designed by his friend Philip Webb. The house resembled medieval buildings with its pointed roof, gothic arched windows and doors, fenced garden. The furniture was made in 1861 in Morris's company that worked like a medieval workshop. Morris was against the fact that the elements of the interior architecture were the result of factory production. He advocated for art to be for people and made by people themselves and wanted to appeal to the wider masses. Aesthetic concerns about daily use production and awareness of this issue arouse thanks to Morris. All kinds of items that could be used in daily life were designed in the workshop. The designers were Morris, Rosetti and Edvard Jones. It played an important role in raising the art appreciation of the public (Figure 8). They were influenced by the two-dimensional surface decoration, patterns and drawings of medieval miniatures [24]. 


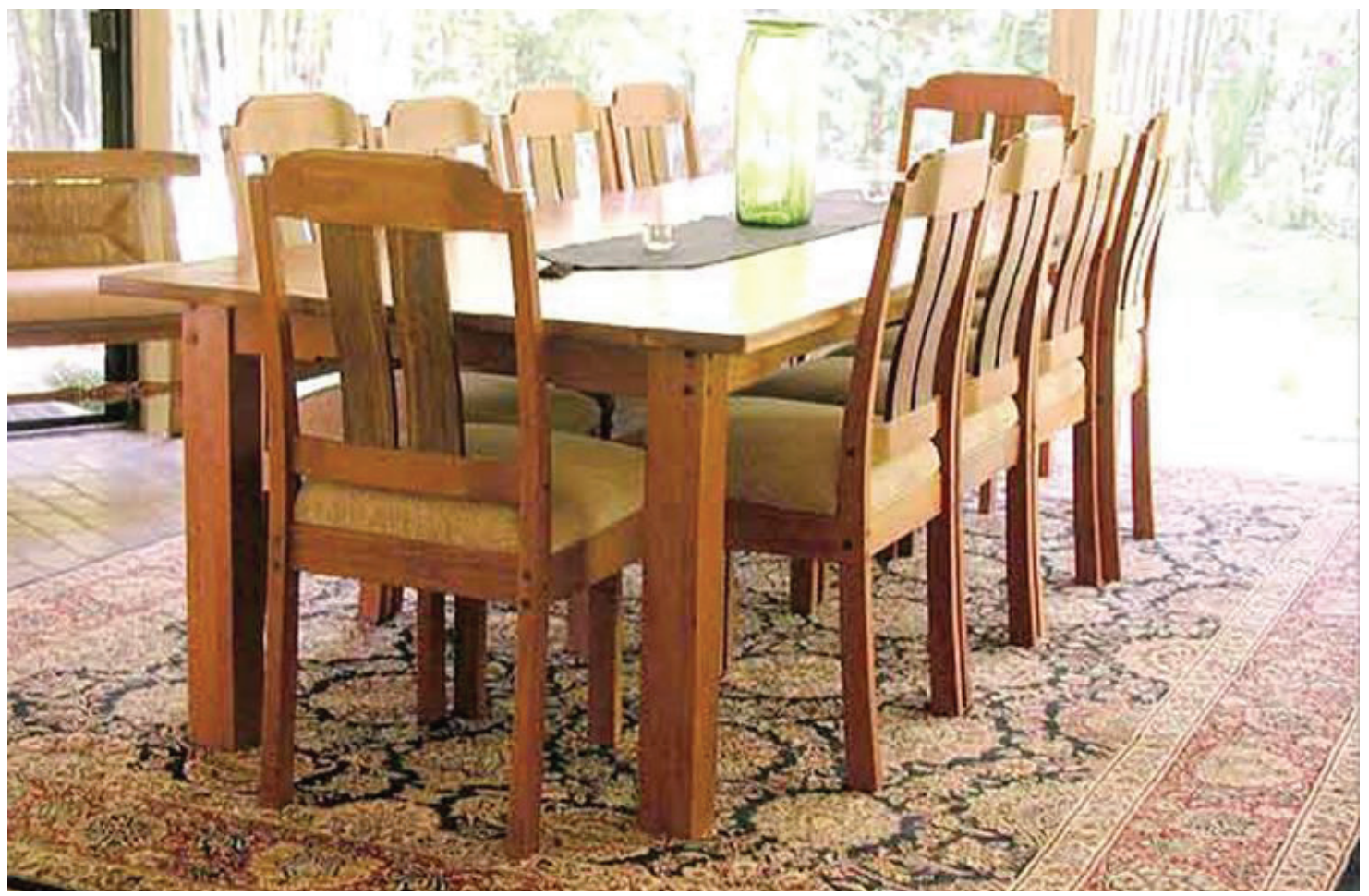

Figure 8. Arts and Crafts Style Dining Table and Chairs [25]

\subsection{Art Nouveau}

After the Arts and Crafts movement, which opposed eclecticism and mechanization after the second half of the VIX century, Art Nouveau became widespread in Europe and America between 1895 and 1905. "The plainness and functionality of the furniture and arts of Arts and Crafts movement"gave clues to future movements. Especially in the USA, furniture design and interior design were greatly influenced by this movement in the end of the VIX century and in the beginning of the XX century. The ideal of handworkmanship developed by Arts and Crafts was applied and developed by Art Nouvea, which was born after it and was an opposing movement to a certain extent. At the end of the VIX century, there was an opening to new worlds such as the Eastern world, Japan, and China. Examples of the Art Nouveau movement are seen all over the world. This trend was accepted as the first break with traditional art. The term "Art Nouveau" comes from S. Bings' shop in Paris. In Germany, the name Jugendstil, a newspaper that began to appear in 1896, is used [26]. This style, which is a movement influential in architecture and decoration, is called Liberstil in Italy and Style Liberty in England and Modern Style in America. "The movement, which brings a new understanding of form in Europe, will adopt the slogan "To every age its art, to every art its freedom", which can be read at the entrance of the Secession building in Vienna. Belgian Henri Van De Velde, one of the theoreticians of this movement, mentioned that the British Arts and Crafts movement never got over the medieval influence in 1894 and he grounded on the beauty that found in the machines. Van De Velde, who sees a great future for iron, steel, aluminum, celluloid and cement, stated that he wants to see vivid, strong and clean colors, energetic and strong forms, reasonable constructions that we lost on household goods as well, he praised new British home household goods that got rid of adornments. [27]. Art Nouveau is based on neither plainness nor antiquity in architecture. It is a sort of transition style. Iron is used in herbal form both as a carrier and as a decoration item. Cast iron has a longlife carrier and decorative meaning. Carrier items are not covered by an additional decorative item. Art Nouveau was influenced by the botanical books from the far east. Floral motifs, flowing forms, curved 
lines, linear quality, fine and elegant drawings, waving have become important. Pioneers of decorations with plant forms are William Morris, Arthur H. Machmurdo in England, Henri Van De Velde in Belgium, and Levis C. Tiffany in the USA. The school named Nancy in France also led this trend. The founder of the school, Emile Galle, did glass and metal works as well as furniture designs. S. Bing, who traded art and marketed furniture imported from the Far East in Paris, opened a new era in French furniture production. As he transformed his shop into an art center, he changed its name to Art Nouveau-New Art [28].

The most famous Art Nouveau designers are both architects and furniture designers. This is also same for Hector Guimart, Henry Van De Velde, Scottish architect and designer Charles Renni Mackintosh, Spanish Antonia Gaudi. German Richard Riemerschmid (1868-1957), who completed the Munich academy, draws attention to a plain, simple design and functionality in the Art Nouveau chair he designed for the music room in 1899. The curved iron bars on the diagonal side are sturdy and provide musicians an opportunity to move their arms freely. It is possible to see the Art Nouveau decoration features in the walnut buffet designed by Louis Majorelli (1859-1926) for the French company called Chicoreé. Plant and leaf motifs, curved lines and geometric shapes, which took place scarcely, draw attention (Figure 9).

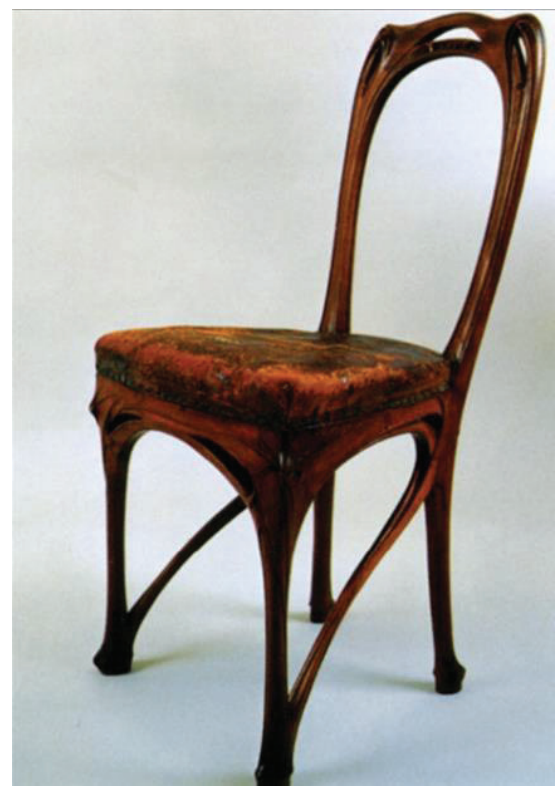

Figure 9. Hector Guimard's Collet Mansion Designed for Dining Hall (1898-1900) [29]

\subsection{De Stijl}

Teo Van Doesburg and Piet Mondrian created a new style, aiming to get the art out of the individual consciousness and bring it to social consciousness. Geometric shapes such as basic round, square, rectangle, and primary colors such as blue, red and yellow were preferred in De Stijl movement. Doesburg "When you scrape the nature out of the outer appearances, the main structure will remain." he said. De Stijl scholars believed that an art that does not rely on the public could not come to life. In an article written by Doesborg in De Stijl magazine, he said that "We must understand that art and life are no longer separate domains." [30]. Asymmetrical lacquered and wooden table produced in 1923 is an example of this. The table is a parallel work with the Red - Blue chair, which was Rietvelt's earlier work. Horizontal and vertical surfaces painted red, blue black, yellow and white are seen. Rietvelt also used De Stijl forms on this table. The table designed for the Schröder House has the asymmetrical style of the house (Figure 10). This style is separate from many modernist architectures of the 1920s [31]. 


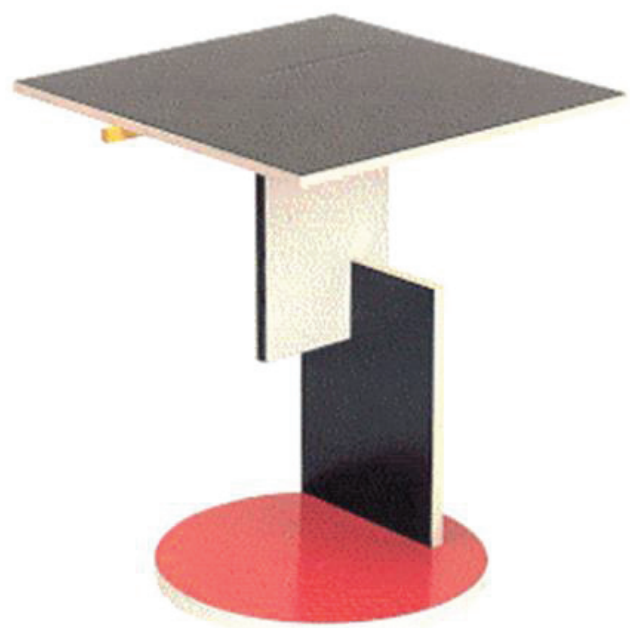

\subsection{Bauhaus}

Figure 10. Gerrit Rietvelt designed by Schröder House (1923) [32]

The foundations of Bauhaus, one of the important milestones of the formation process of modern art and architecture, were created by the architect Walter Gropius in Weimar city, Germany. The movement was developed by new generations led by great artists such as Kandinsky and Klee.

Bauhaus School, which was one of the most important centers of the European avant-garde between the two World Wars, influenced the entire continent as the leading art center of the XX century until it was closed by the Nazis. Bauhaus tried to re-establish the link between art, architecture, and industry, which was broken since the Renaissance and left a legacy developing XX century contemporary art understanding. It ensured that this understanding was placed in a wide frame ranging from architecture to textile design, from graphics to furniture, from ceramics to sculpture, from painting to photography.

Members of the Bauhaus carried out their photography works in a documentary perspective rather than an artistic dimension. They tried to create a new and objective perspective with their unconventional approaches and compositions.

In the 1920s and 1930s, a German design school became the pioneer of a style that would later be called "Modern". Based on the philosophy of todays "Design comes after functionality." the Bauhaus style was quite plain and bright. The materials used are; steel pipes, plywood, leather, and plastic. Colors are mostly limited to black, white, brown, and gray. Famous designers who followed this style are; Mies Van Der Rohe, Marcel Bruer, Charles and Ray Eames, Alvar Alto and Aero Saarinen.

The furniture produced at the beginning of the XX century appeals to the middle class with rich and real art buyers. The designer had to take into account both groups. "A group of architects and artists influenced by Japanese art developed a new style in an Art School in Glasgow, a Scottish port city. They preferred little decoration and black and white colors. Charles Rennie Mackintosh, who was at the head of the group in the last periods of Art Nouveau, used forms created by fine, horizontal, and vertical lines."[33]. The chairs designed by Mackintosh in 1897 show Art Nouveau's late period examples with simple decoration elements. As an example of the Geometric Art Nouveau, the geometric forms on the chair made for the Hill House in Helensburgh draws attention to the emphasis of horizontal and vertical lines and plainness and little ornamentation (Figure 11). 


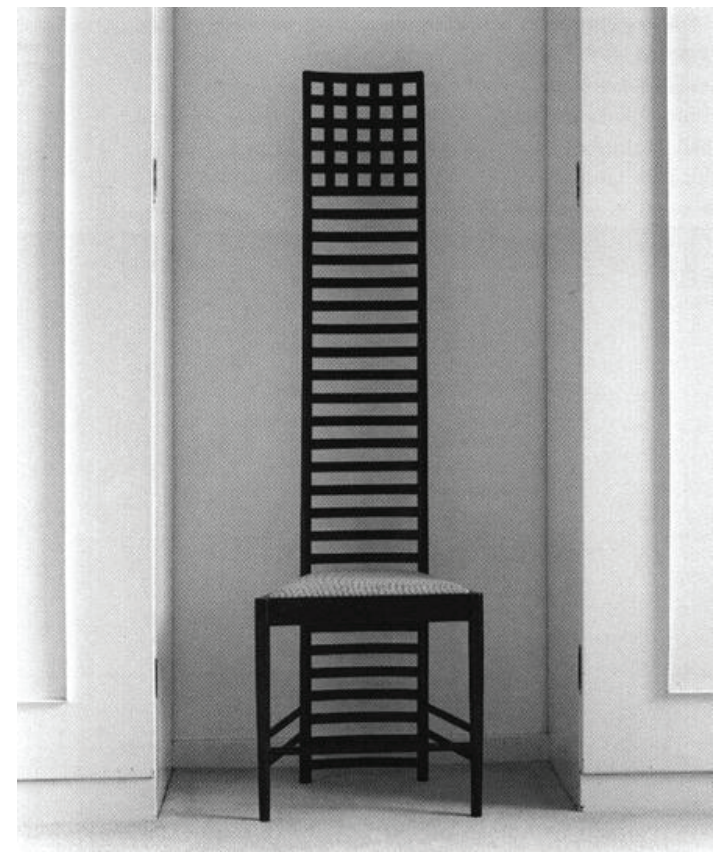

Figure 11. Mackintosh, Ladder Chair [34]

\subsection{Post Modernizm}

In the 1950s there were important Italian companies such as Zanotta, Cassino, Capellini, Molteni. Designers were designing furniture for these companies. Armchairs made of polyurethane foam, consumption and pop culture synthesis vacuum packaged armchairs, plastic armchairs were temporary but fantastic furniture of the period. Crazy examples and female figure designs of pop art are interesting. "Symbolist, expressionist, surrealist, pop, anti-design, low tech, high tech, postmodern, memphis, new design, brutalist, environmentalist, arabesque are the trends and fashion that shape the design of our century."

Post Modernism, which emerged as a reaction against the modern in the 1970s, also manifested itself in furniture. There was no retroactive and irony in modern art. Postmodernist furniture revitalizes historical trends. It creates new forms, inspired by old forms. There are designs goes back to Kitsch. They utilize all behaviors and trends, all forms, elements, and richness of form. "In the 1980s, Ettore Sottsass said "We use everything we do today. Our productions are devoted to life, not to future generations.' In 1981, he produced legendary symbols on the shelves he designed and he produced furniture made of colored plastic." [35]. In Hans Hollein's work named 'Marilyn Sofa' in 1981, it is seen that a rare wooden and old sofa fabric were used together. It has an unsymmetrical curved form. It is an organic design. It is realistic and comfortable thanks to the moldable artificial foam and flexible upholstery fabric. Hands and gloves, like the Lips, inspired furniture as they can grasp people or as they are a carrier element (Figure 12). 


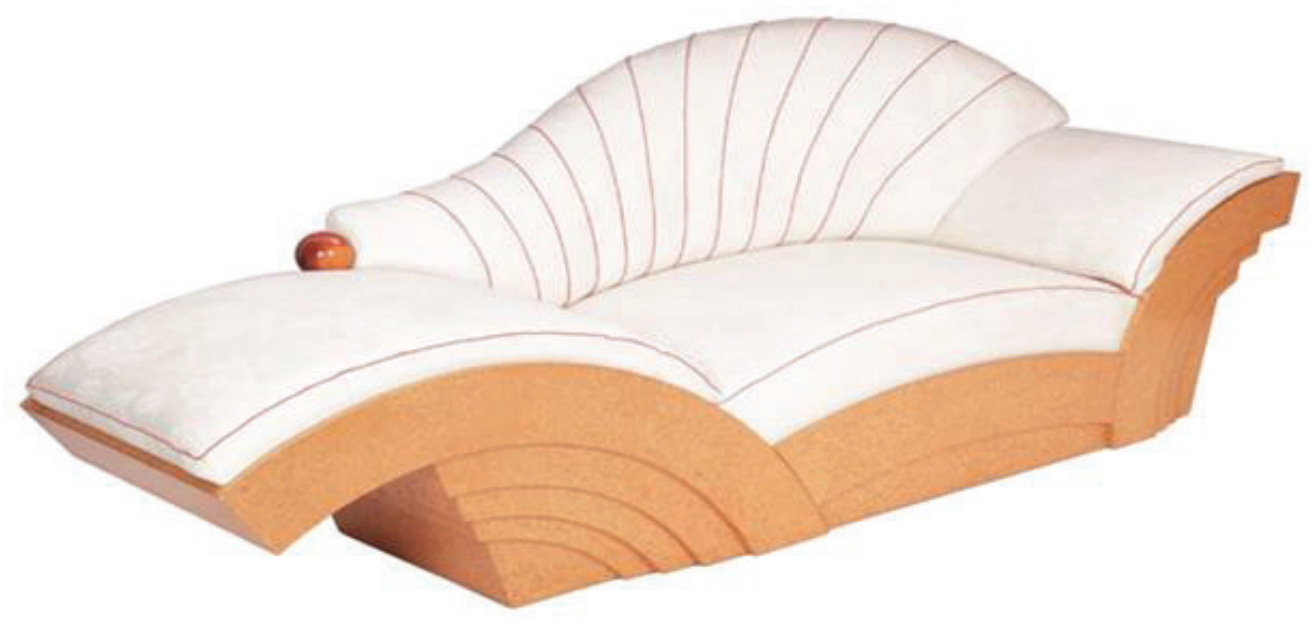

Figure 12. Hans Hollein, Marilyn Sofa, (1981) [36]

\section{CONCLUSION AND DISCUSSION}

The transition of people to the settled lifestyle has been an important step in the socialization process. While transitioning to settled lifestyle brought a life under one roof along with it, this situation cost many years in history. Being able to live comfortably after meeting the primary needs has brought new needs beyond just living under four walls and a roof. Thus, as well as the need for a place to live, the effort to make this place, house livable increased the use of furniture rapidly. The use of furniture started to gain importance in terms of functionality to comfort and then, as a next step, conformity with aesthetic understanding.

All these social developments were undoubtedly accompanied by artistic and architectural movements. Thus, Baroque, Art Noveau, Gothic and Art Deco styles came to life in the design and products of the furniture industry. The concept of furniture was transformed into a meta that reflect the lifestyle shaped by socio-cultural relations, rather than being a need figure.

In 1900 s, the industrial revolution showed its effect within the framework of production relations of furniture sector, as in every sector. Small-scale enterprises started to be replaced by industrial enterprises utilizing mass production. Naturally, production increased by the increased competition brought about the constant renewal of the goods produced due to the fact that the markets could not be shared.

In light of all these developments, furniture manufacturers had a tendency to offer ergonomics and aesthetics in addition to functionality. With the increase of modular furniture production, the concept of individual usability gained value. At this point, not only a contract-based and fixed product was offered to the consumer, but also the manufacturers started to offer products that can be installed and used according to the consumers' wishes and desires. 


\section{REFERENCES}

[1] Hasol, D. (2010). “Ansiklopedik Mimarlık Sözlüğü” (11. Basım), İstanbul. YEM Yayınları

[2] Acar, (1992). “ Yap1-İç Mekan Bütünlüğü İçinde Sabit Mobilyanın Çözüm Örnekleri Üzerine Bir Araştırma.” Yayınlanmamış Yüksek Lisans Tezi, İstanbul Üniversitesi

[3] Coates, M. Brooker, G. ve Stone, (2011), “Görsel İç Mimarlık Sözlüğü̈” İstanbul. (çev: N. Işık), İstanbul. Literatür.

[4] http://global.britannica.com/technology/furniture

[5] http://wikiwand.com/tr/mobilya

[6] Ching, Francis D.K. (2004). "Mimarlık: Biçim, Mekan ve Düzen (2.bask1), İstanbul: Yap1 Yayınları

[7] Lucie-Smith, E. (1993).” Furniture: A Consice History”, London, Thames and Hudson Ltd.

[8] Boyla, O. (2011). "Mobilya Tarihi”, İstanbul.

[9] Colomina, B. (2011). "Mahremiyet ve Kamusallık Kitle İletişim Aracı Olarak Modern Mimari” (Çev: A. Ufuk Kılıç), İstanbul. Metis.

[10] Küçükerman, Ö. (1978). "Kişi-Çevre İlişkilerinde Çağdaş Gelişimler ve Oturma Eylemi, İstanbul: İstanbul Devlet Güzel Sanatlar Akademisi.

[11] Dinçel, K., Işık, Z. (1979). "Mobilya Sanatı Tarihi”, İstanbul: Milli Eğitim Basımevi

[12] Burchell, S. (1991). “A History of Furniture” Newyork: Harry, N. Abrams Inc. Publishers.

[13] www.nationalgeographic.com.tr/makale/keşfet/çatışma-keşfedilmeden-önce/2625

[14] Blackmere, Robbie, G. (1997). "History of Interior Design and Furniture History”, Toronto: Willey Publishers.

[15] https:// tr.pinterest.com

[15] Gürhan, T. (1990). “İktisat Tarihi”. İstanbul: damla Ofset.

[16] www.wallswithstories.com/furniture

[17] İlkin, A. (1973). “Ak İktisat Ansiklopedisi”, cilt:2, İstanbul: Ak Yayınları.

[18] Torun, T. (2003). “Endüstri Toplumunun Oluşmasında Etkili Olan İktisadi ve Sina-i Faktörler” C.Ü. İktisadi ve İdari Bilimler Dergisi, Cilt:4, sayı:1 s:181-195.

[19] www.fikirtv.com/barok-mobilya-sanati

[20] www.moderniste.cz

[21] www.antikalar.com

[22] www.bonluxat.com

[23] www.wolfsomian.fiu.edu.

[24] Küçükerman Ö. (1996). "Endüstri İçin Ürün Tasarımında Yaratıcılık”, YEM Yayınlarl, İstanbul

[25] Charlotte \& Fiell P. D. Of T. 20th. Century, Taschen. S.55

[26] www.vikipedia.org, (2006-01)

[27] www.evdose.com 
[28] www.sandalye.infosss

[29] www.arch.colombia.edu

[30] www.arkitera.com

[31] Yaylalı H. (2000). “Tasarımda Modernizm”, $A D$ 83, İstanbul

[32] www.culture.gouv.fr

[23] www.berlin-turkish.com

[34] Charlotte \& Fiell P. D. Of T. 20th. Century, Taschen. S.124

[35] Malcom H. "In The Nouveau Style", Thomas \& Hudson

[36] www.robbrertluxuryhome.com

\section{ŞERIF TOLGA ERDEM, Lecturer}

He was born in 1975. He is working as a lecturer in the Department of Interior Architecture and Environmental Design at Istanbul Kültür University. He completed his undergraduate education in 2002 in MSGSU, Faculty of Architecture, Department of Industrial Design, and his master's degree in 2007 at Istanbul Kültür University, Institute of Science and Technology, department of Interior Architecture. He is currently a PhD candidate at MSGSU, Department of Interior Architecture. He has been involved in various design projects and has opened numerous painting and illustration exhibitions. He continues his academic studies at national and international level, specializing in interior design, product design, reinforcement design, furniture design. 